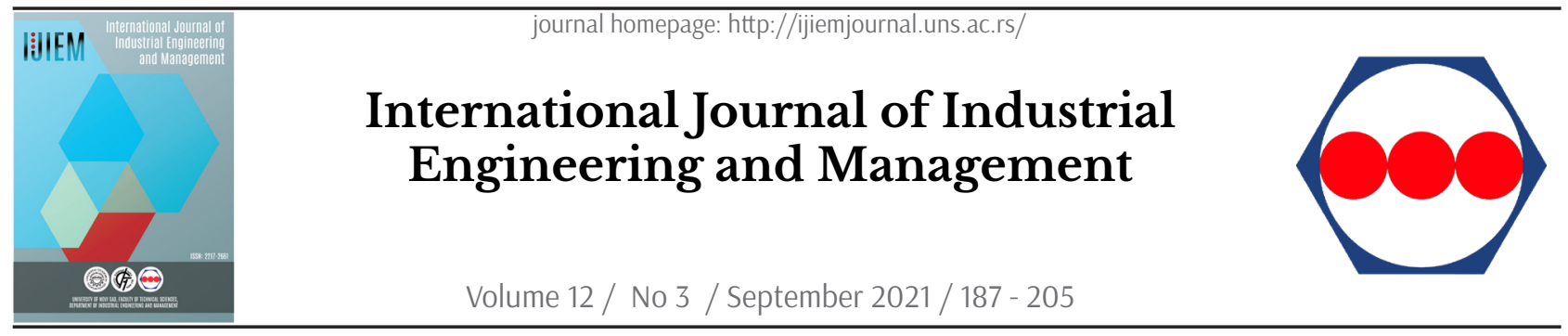

Original research article

\title{
Exploring the relationship between individual and bundle implementation of High-Performance Work Practices and performance: evidence from Spanish manufacturing firms
}

\author{
A. Manresa ${ }^{a *}$, A. Bikfalvi ${ }^{b}$, A. Simon $^{c}$ \\ a International University of Catalunya, Department of Economics and Social Science, Barcelona, Spain; \\ ${ }^{b}$ University of Girona, Department of Business Administration and Product Design, Girona, Spain; \\ C Autonomous University of Barcelona, Department of Business Administration, Barcelona, Spain
}

\section{A B STRACT}

Companies aiming to increase their firm performance implement specific practices known as High Performance Work Systems (HPWS). Uncertainty remains, however, about the structures included in them. The main purpose of this paper is to analysis the difference between implementing specific HPWP separately or as a HPWS, and their effect on performance aspects, using the Spanish subsample of the European Manufacturing Survey. The results show that these firms' implementation rates are relatively low compared to the European average, despite over $50 \%$ of respondents implementing some of the practices studied (individually or as a bundle).

\section{ARTICLE INFO}

Article history:

Received March 16, 2021

Revised July 9, 2021

Accepted July 12, 2021

Published online September 14, 2021

Keywords:

Firm performances;

Quality;

High performance work system;

European Manufacturing Survey;

*Corresponding author:

Alba Manresa

amanresa@uic.es

\section{Introduction}

Firms are challenged with dealing with rapidly changing global, market and customer dynamics to achieve sustainability [1]. To cope with these changes, they must focus on being able to manage their needs by knowing the firm's production requirements and displaying proactive behaviour that might lead to better results [2]. A particular interest in High-Performance Work Systems (HPWS) has thus emerged. A common belief related to HPWS is that the main source of competitive advantage is the firm's employees [3,4]. A growing body of research from various disciplines promotes HPWS as a modern approach for productive enterprises, characterizing them as a type of Human Resource Practice that enhances firm performance [5]. Therefore, it is important to understand how HPWS are designed as bundles of HPWP that generate synergies in an integrated system where individual practices reinforce one another to enhance organizational performance. In this line, it becomes necessary to understand how 
the individual practices play a role individually and jointly within the structure of these systems. This will allow the development of knowledge in this area and will influence how and to what degree organizations implement these systems [6].

Despite the growing body of literature in the HPWS field, there is as yet no consensus on an adequate definition or a narrow description of the group of practices that may fit HPWS. This paper understands HPWS as a bundle of individual but interlinked practices that in conjunction develop, motivate, and retain employees to achieve better organizational performance as a way of generating value for a firm by reducing costs and raising productivity [6].

The HPWP analysed within the general framework of a HPWS in the present paper are: the method of $5 \mathrm{~S}$, a system for organizing spaces so that work can be performed efficiently, effectively, and safely; standard work, the combination of processes, procedures, and visual work instructions explaining the best practices for performing a task according to standard; integration of tasks, which refers to planning, operating, and controlling functions with the machine operator; standardized methods for health and safety conditions; and different training practices (seminars and training opportunities with specific activities, and seminars and training opportunities with an interdisciplinary focus and on-the-job training).

There is also little agreement about what is considered a good or the best combination of practices [7]. Danford et al. (2008) [8] and Guest (2011) [9] find that despite extensive research in this field of study, the relation between performance and HPWS is still not fully understood. To be able to understand the impact HPWS have on performance, it is important to first understand what these practices are. Arthur (1994) [10] analyses performance gains from enhanced commitment, identifying a significant relationship between commitment and performance.

Lack of agreement, however, has led to a huge growth in the HWPS literature. Ramsay et al. (2000), Harley (2007) and Macky \& Boxall (2007) [11-13] all conclude that HPWS present a positive correlation with employee commitment, while others have observed a negative relation [14] or no relation at all [12]. Despite abundant literature providing evidence of the positive link between HPWS and various organizational outcomes [15,16], considering performance aspects such as innovation [17], quality [Pot et al., 2016; Paauwe, 2009], operational efficiency [19], and turnover [20,21], there is still a need for further research to this effect [17].

The main objectives of this paper are: first, to analyse the implementation degree of HPWS in the Spanish manufacturing context; and second, to examine the impact of HPWP - both separately and as a system - on different performance aspects. Studying the impact of HPWS on performance aspects is relevant for a variety of reasons. First, HPWS can be considered a strategic choice and option for work organisation, and having a fair understanding of their effect on performance is a driver for implementation. Second, implementing HPWS might require specific resources and capabilities, as well as an integrated, organisation-wide, effort-intensive change. From an optimisation perspective, knowing which combinations influence different performance facets might help practitioners to prioritise, plan, and implement those that best support their aim and vision. Third, we contribute to the HPWS literature which, although stable in its conceptual boundaries, is in continuous evolution due to the ever-changing nature of new emerging work practices, and especially those linked to the rise and spread of technologies. According to the latest European Innovation Scoreboard 2020 [22], Spain is one of the 13 countries in the moderate innovator category, hence the results could represent a whole group of countries. Following this line of argumentation, focusing attention on a moderate innovator country also makes the findings imaginable and conceptually translatable to other contexts.

The remainder of the paper is organised as follows. Section II presents the theoretical background of the research in the form of a literature review, describing in greater detail the most important conceptual pillars and including the main definitions of HPWS and related practices. Section III introduces the research method applied, detailing the research design, the variables, the data collection method. and the method of analysis. Section IV is an analysis and discussion of the most important results, and the conclusions of the study, along with the limitations and recommendations for future research, are presented in section $\mathrm{V}$.

\section{Theoretical background}

\subsection{The HPWS lexicon}

Prior to studying the different effects of individual practices and bundles of HPWS on performance, and to avoid misunderstandings in the conceptualization process, the wide and overlapping lexicon of HPWS must be discussed. David Nadler (1990)'s [23] main contribution to this effect was the integration of so- 
cial and technical aspects as part of the organisation's basic resources, thus creating the concept of HPWS. [9] subsequently focused on bundles of Human Resources Management (HRM) practices. A thorough review of the different papers and empirical studies in the literature has been made to analyse HRM and organizational performance, with a particular focus on the HPWS model [24]. Due to the varied usage of the term HPWS, there is still a lack of agreement on its meaning [25-26]. Some authors, nonetheless, have come up with their own descriptions. According to Huselid (1995) [27] and Delaney \& Huselid (2016) [28], a HPWS is composed of a group of HPWP which, when aligned with organizational strategy, organizational performance, and productivity, enhance performance. Ubeda-Garcia et al (2018; p.398) [26] argue that 'an HPWS can broadly be understood as including a range of innovative human resource practices and work design processes which, when used in certain combinations or bundles, are mutually reinforcing and produce synergistic benefits'.

HPWS have recently been described in other ways. The Organisation for Economic Co-operation and Development [29] defines them as the practices implemented by organizations that move towards a flatter and less hierarchical structure, where people work in teams with greater autonomy based on higher levels of trust and communication. Table 1 is a summary of the most important definitions of HPWS.

\subsection{HPWP - a review of the literature}

Previous studies have analysed the relationship between either the whole HPWS and organizational performance, or selected individual HPWP and organizational performance [48]. Becker \& Huselid (1998) [24] conclude that it is more relevant to study the influence of each practice on organizational performance, but that this must be done in one single model because examining each element in isolation does not control for the effect of the rest of the practices. Other authors, however, suggest that the effects HPWP have on employees and organizations are greater when they are introduced as a group of practices rather than individually $[49,50]$. One reason for this could be that when a HPWS affects organizational performance, this effect cannot be transformed into the effects of individual practices. Despite the lack of agreement about what is a good or the best bundle of practices and how this should be defined, the results and evidence emphasize the positive effects on organisational performance [28].

Irrespective of definitions, the main question is 'individual or bundle' of practices [51]? Companies should align the implementation of specific practices with their objectives and strategy [20,52]. When the aim of the firm is aligned with its strategy, implementing HPWS enhances employees' skills, abilities, and knowledge, and this is associated with positive outcomes [53] such as higher productivity [54], better quality products [55], enhanced safety performance

Table 1. Definitions of HPWS

\begin{tabular}{|c|c|c|}
\hline Authors & Year & Definition \\
\hline Huselid [27] & 1995 & $\begin{array}{l}\text { HPWS comprise a system of HR practices which, when aligned with organizational strategy, are } \\
\text { designed to increase organizational performance and productivity. }\end{array}$ \\
\hline Osterman [30] & 2000 & $\begin{array}{l}\text { A general description of a diverse set of practices. Researchers tend to require more than one } \\
\text { practice be in place, and some researchers also set a minimum employee participation level. }\end{array}$ \\
\hline Way [31] & 2002 & $\begin{array}{l}\text { A set of distinct but interrelated HRM practices which together select, develop, retain, and moti- } \\
\text { vate a workforce that possess superior abilities and who apply these abilities in their } \\
\text { work-related activities. These work-related activities result in these firms achieving superior } \\
\text { intermediate-term indicators of firm performance and sustainable competitive advantage. }\end{array}$ \\
\hline Tamkin [32] & 2004 & $\begin{array}{l}\text { Organizations that move toward a flatter and less hierarchical structure, where people work in } \\
\text { teams with greater autonomy based on higher levels of trust and communication. }\end{array}$ \\
\hline Bauer [33] & 2005 & $\begin{array}{l}\text { HPWS for firms to achieve higher flexibility, higher product quality, and higher performance, } \\
\text { while remaining cost competitive by inducing workers to work harder, and by using the skills } \\
\text { and knowledge of their employees more effectively through placing decision authorities closer to } \\
\text { those with the relevant knowledge. }\end{array}$ \\
\hline Godard [34] & 2004 & $\begin{array}{l}\text { Promoted as a 'best practice' for employers on the grounds that the practices associated with it } \\
\text { yield performance levels above those associated with more traditional workplace and } \\
\text { employment relations practices. }\end{array}$ \\
\hline $\begin{array}{l}\text { Marchington \& } \\
\text { Wilkinson [35] }\end{array}$ & 2008 & $\begin{array}{l}\text { A bundle of HR practices has the potential to contribute to improved employee attitudes, } \\
\text { behaviours, lower levels of absenteeism and labour turnover, and higher levels of productivity, } \\
\text { quality, and } \\
\text { customer service. }\end{array}$ \\
\hline
\end{tabular}


Parsons \&

Necochea [36]

Katou [16]

Boxall \& Purcell [25]

Subramony [37]

Soens et al. [38]

O'Regan [39]

Kroon et al. [7]

Euro found

Working Con-

ditions Survey

[40]

Euro found

Working

Conditions

Survey [40]

Ismail [15]

Kumar et al. [41] 2016

Posthuma et

al. [6]

Mihail et al. [42] 2013

García-Chas et

al. [43]

Euro found

Working

Conditions

Survey [44]

Lin \& Liu [45]

2016

Daspit et al.

[46]

Kooij \& Boon

[47]

Ubeda-Garcia et al. [25]
Work system that maximizes the fit between the social and technology systems.

Modern approach for productive enterprises and characterized as a form of HRM that enhances firm performance outcomes.

HPWS constitute a claim that there is a system of work practices that in some way leads to superior organisational performance. There are three concepts explicitly embedded in this proposition: performance, work practices, and systemic effects. Combining practices into a bundle rather than individual practices, which shapes the pattern of interactions between and among managers and employees.

Multiple complementary practices are typically considered as superior to individual best practices in influencing firm performance.

Coherent set of HRM practices including selective hiring, promotion from within, extensive training, performance appraisal, employee participation, information-sharing, teamwork, and broad job design, which have repeatedly been shown to relate positively to firm performance

Describes the contended concept of an optimal bundle of HR practices associated with firm performance.

Modern employee management practices.

Diffusion of specific organizational practices and arrangements seen as enhancing the company's capacity for making incremental improvements to the efficiency of its work process and the quality of its products and services.

Specific subset of HR practices commonly interpreted as whether employees work individually or in teams, and may also include work scheduling and working time. Having a broad focus on any type of performance outcome and not just those associated with the goal of employee involvement or commitment.

HPWS are designed to be matched with organizational strategies that focus on cost cutting and competitive product pricing, and are varied by cost cutting business strategies in different work environment settings.

A set of practices that typically comprise comprehensive recruitment and selection, incentive-based compensation, performance management, extensive employee involvement, and detailed training initiatives. HPWS is a name given to a set of management practices that attempt to create an environment within an organization where the employee has greater involvement and responsibilities. The essential idea behind this intervention is to identify organizational configurations that help organizations achieve the best 'fit' between the four cornerstones of organizational architecture: information, technology, work, and people

The HR system that enhances employee competencies, commitment, and productivity. Coordinated bundle of practices that create synergistic effects wherein certain practices reinforce one another to increase organizational efficiency and effectiveness.

Specific combination of HR practices, work structures, and processes integrated into an overall system to enhance employee involvement and performance.

System of interconnected HR practices that aim to attract, select, manage, and retain the highest quality human capital.

Emphasises the decentralisation of decision-making. It also focuses on several other aspects: the reduction of functional specialisations (resulting in more multitasking); increased teamwork in general, and specifically in self-managed teams; a shift in the internal structuring from functional divisions to market- or process-oriented units that provide greater flexibility, employee account ability, and customer orientation

The nature of a potentially intermediate mechanism facilitating the link between HR practices and organizational performance.

A set of practices that have a vital effect on the effectiveness of the organization's activities.

A bundle of practices used to manage human resources by focusing on three aspects related to employees' ability, motivation, and participation.

A range of innovative human resource practices and work design processes which, when used in certain combinations or bundles, are mutually reinforcing and produce synergistic benefits. 
[56], and increased turnover [21]. In this line, Kumar et al. (2016) [41] use a method to develop relations between practices. The first of the above mentioned practices is the additive relation, which is when the practices involved have independent and non-overlapping effects on outcome [57], and the second is the interactive (synergistic) relation, where the effect of one practice depends on the level of the other practices. Becker \& Huselid (1998) [58] distinguish between two types of interactive relations: powerful connections, which represent combinations of practices that strengthen each other and can create HPWS, and disjunctive combinations, which reveal a negative synergic connection among those practices [59].

Table 2 shows the analyses of articles on HPWS published over the last 20 years, and the practices studied in each of them. As can be seen, all the referenced articles apply more than one HPWP, with the minimum and maximum number applied standing at 2 [46] and 13 [34], respectively. The most implemented practice in the articles studied is T\&D (24 investigations), followed by teamwork (14). The least implemented are those referring to task complexity (1) and problem solving activities (3), and those related to quality (quality circles (3) and TQM practices (3).

\subsubsection{Innovation performance}

The EU Commission emphasises the significance of the human factor for developing innovation within the company since both quality and innovativeness are influenced by the knowledge, skills, and capacities of the employees involved [40]. The evidence suggests that, in effect, increasing knowledge sharing and idea generation practices in a firm is positively associated with an increase in innovation commitment. The adoption of HPWS is considered a requirement to facilitate other forms of innovation within the company. This is important because firms that present better innovation outcomes are those that have better competitive advantage [18].

Studies authored by Foss \& Laursen (2005) [63] and Zoghi et al. (2010) [64], among others, focus on the effects that new and innovative organizational practices have on companies. While all the previous authors find positive effects, the question remains as to which combination of different kinds of practices presents the largest impact on innovation. A previous analysis of HPWS by Zoghi et al. (2010) [64] shows that combinations of workplace practices such as responsibility, health, and security measures, task integration, and training opportunities are related to better levels of company innovativeness. Positive links have also been found between some specific HPWP, such as training, and innovation performance. This relation is again evidenced in Chen and Huang (2009) [19], which states that implementing training enhances knowledge, skills, and innovative capabilities.

\subsubsection{Operational efficiency}

Ichniowski, et al. (1997) [65] find that companies that implement HPWS present better results in operational efficiency outcomes, and that these results are better when the practices are introduced as a bundle. Likewise, Black \& Lynch (2004) [66] find that growth in productivity levels may be explained by implementing and adopting practices such as training, task integration, and health and safety activities, among others, and that companies that introduce some of these practices experience higher operational efficiency. More recently, the European Comission (EC) showed that HPWS comprised of practices such as training, performance pay, health and security measures, and standardization practices present better operational efficiency performance [44,67]. This is because HPWS increase employees' empowerment and motivation, which in turn increase operational efficiency performance [9].

\subsubsection{Quality performance}

The main outcomes used to analyse the impact of HPWS are quality and customer satisfaction. Previous research provides empirical evidence suggesting that implementing a bundle of complementary practices that include training, task integration, aligned goals, and/or health and security positively affects employees' perceptions of their ability to deliver high-quality offerings to their customers. Consequently, workers' attitudes and quality are considered decisive elements for enhancing customer satisfaction. Authors such as [68] find a link between these practices and customer perceptions of quality, and further evidence supporting this causal connection has also emerged [69]. More recently, a study based on work organization and innovation developed by the European Foundation for the Improvement of Living and Working Conditions (2017) [60] concluded that companies that implement groups of practices that include lean management, health and safety measures, training, integrated working practices, and employee involvement are the ones most commonly 
Table 2. Implementation of HPWP throughout the literature review

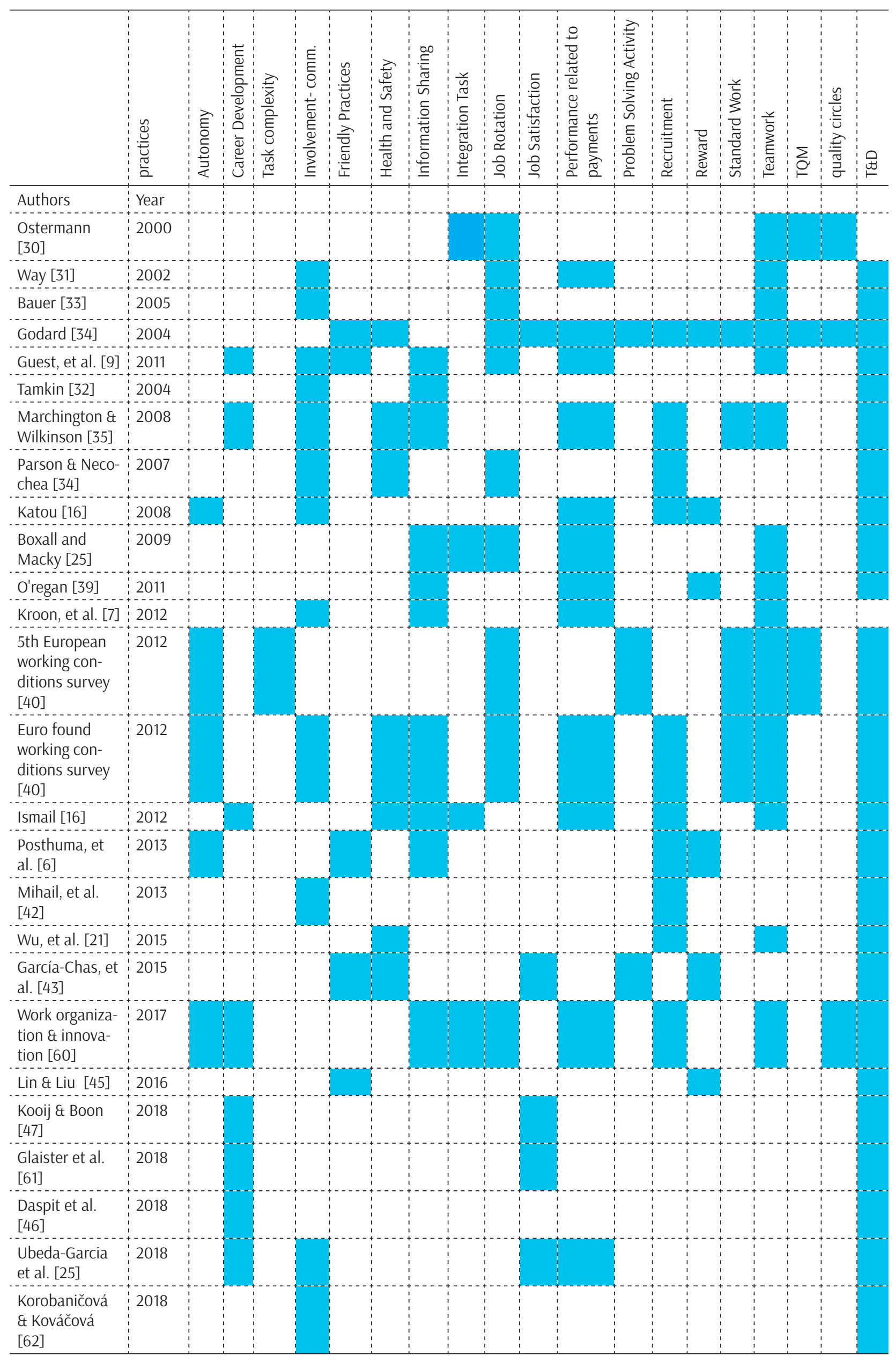


associated with increased company productivity, improved quality and, to a lesser extent, less customer complaints [60]. Consequently, there is ample conceptual and previous empirical justification for accepting the links between HPWS and quality outcomes.

\subsubsection{Turnover}

In what is considered to be a seminal paper, Huselid (1995) [27] analysed the link between organizational performance and HPWS. Several meta-analyses followed, including Combs et al. (2006) [70] and Subramony (2009) [37], adding to the large and accumulating body of research. An analysis of more than 90 studies with statistical findings on the effects of HPWS on firm performance [70] has produced inconclusive results. Wood and Wall (2007) [71] find a positive effect on most of the firms studied. In contrast, some smaller studies based on statistical analyses find a negative association or no relation at all [72].

\subsection{Conceptual framework}

The present paper considers two perspectives in the analysis of the relation between HPWS and organizational performance and how these practices may lead to the desired outcomes at the firm level, be they innovation, operational efficiency, quality, or turnover. Two different approaches have been tested with this aim in mind. First, the universal approach focuses on analysing different HPWP that enhance a specific performance (e.g., [7,21]). It understands that there are specific practices that firms implement independently of the performance they wish to enhance. Hence, this approach focuses on the study of the effects of implementing these practices separately on firm performance [37]. Therefore, the first hypotheses were:

H1: Which individual HPWP separately influences different performance aspects most.

H1a: The individual HPWP that separately influences innovation performance.

H1b: The individual HPWP that separately influences quality performance.

H1c: The individual HPWP that separately influences operational efficiency.

H1d: The individual HPWP that separately influences turnover.

Other researchers such as [43] examine the effect of HPWP following the strategic approach, which analyses the bundle of practices that shapes a system (HPWS) that fits best with the firm's strategy. This bundle of practices must not only align with the goals and strategy of the firm, but the practices themselves must complement one another to gain competitive advantage and a better firm strategy [21]. Therefore, drawing on the argument made above, the second hypothesis was constructed as follows:

H2: Different bundles of individual HPWPs influence different performance.

H2a: Different bundles of individual HPWP influence innovation performance.

H2b: Different bundles of individual HPWP influence quality performance.

H2c: Different bundles of individual HPWP influence operational efficiency.

H2d: Different bundles of individual HPWP influence turnover.

Due to the lack of consensus as to whether these practices should be implemented individually or as a bundle, the third hypothesis tested is:

H3: HPWP implemented as a bundle have a higher impact on performance than individual HPWP.

H3a: HPWP implemented as a bundle have a higher impact on innovation performance than individual HPWP.

H3b: HPWP implemented as a bundle have a higher impact on quality performance than individual HPWP.

H3c: HPWP implemented as a bundle have a higher impact on operational efficiency than individual HPWP.

H3d: HPWP implemented as a bundle have a higher impact on turnover than individual HPWP.

Figure 1 shows the proposed research model, visually representing the expected relationships between HPWS and performance.

\section{Methodology}

As the theoretical and conceptual understanding of innovation has developed, so empirical advances have also been made. With a relatively consolidated conceptual framework of a mature research field, both qualitative and quantitative approaches are present in the body of knowledge and practice. Empirically oriented innovation research has continuously 
evolved due to the introduction of firm-level innovation surveys. Their usefulness relies on collecting primary data on the phenomena of innovation, today regarded as a multi-dimensional issue and one which may differ according to the context, allowing the domination of varying drivers [73]. Moreover, the same authors specify that collecting innovation data via 'true' innovation surveys is the most preferable approach, where a 'true' innovation survey is understood as a survey that is custom designed to collect a full set of innovation data. The most representative international effort in this direction is the Community Innovation Survey [74], with other complementary efforts deployed by research institutes around the world, one of which is described as follows: "The Fraunhofer Institute for Systems and Innovation Research (ISI) has conducted the German Manufacturing Survey every two to three years since 1993. The survey was internationalized in 2001 to meet the demands for internationally comparative data and the European Manufacturing Survey (EMS) was established as a result" [74: 427].

Quantitative in nature, survey data is the most appropriate data to address the type of objective formulated in the present paper, namely if and to what extent HPWS are present in manufacturing establishments and what their effect is on a spectrum of performance aspects. Empirical evidence providing answers to these questions has been collected using European Manufacturing Survey data.

\subsection{Sample}

The data included in this study comes from the largest initiative on manufacturing activities based in European countries, the European Manufacturing Survey (EMS), coordinated by the Fraunhofer ISI Institute, Germany [74]. In the 2015 round - the latest available data for Spain- firms were asked to answer questions on manufacturing strategies, organizational innovation, relocating production, energy issues, and HR issues, among others. Data on performance indicators such as operational efficiency, flexibility, quality, and turnover were also collected. The survey further covered the present and future competitive priorities of the company and the characteristics and configuration of their manufacturing. Innovative outcomes are measured in terms of creating higher performance through launching new products to the company and to the market, new services, and new business models.

The EMS is conducted every three years, each round revised conceptually by international experts, who introduce new concepts that are gaining in importance within the organizational and technological fields of study. The EMS is also highlighted because it is a survey that enables the analysis of individual, groups/sets, and combinations of technological and organisational practices due to its level of detail and specificity. A wide variety of publications use the same sample, including [75-80], among others.

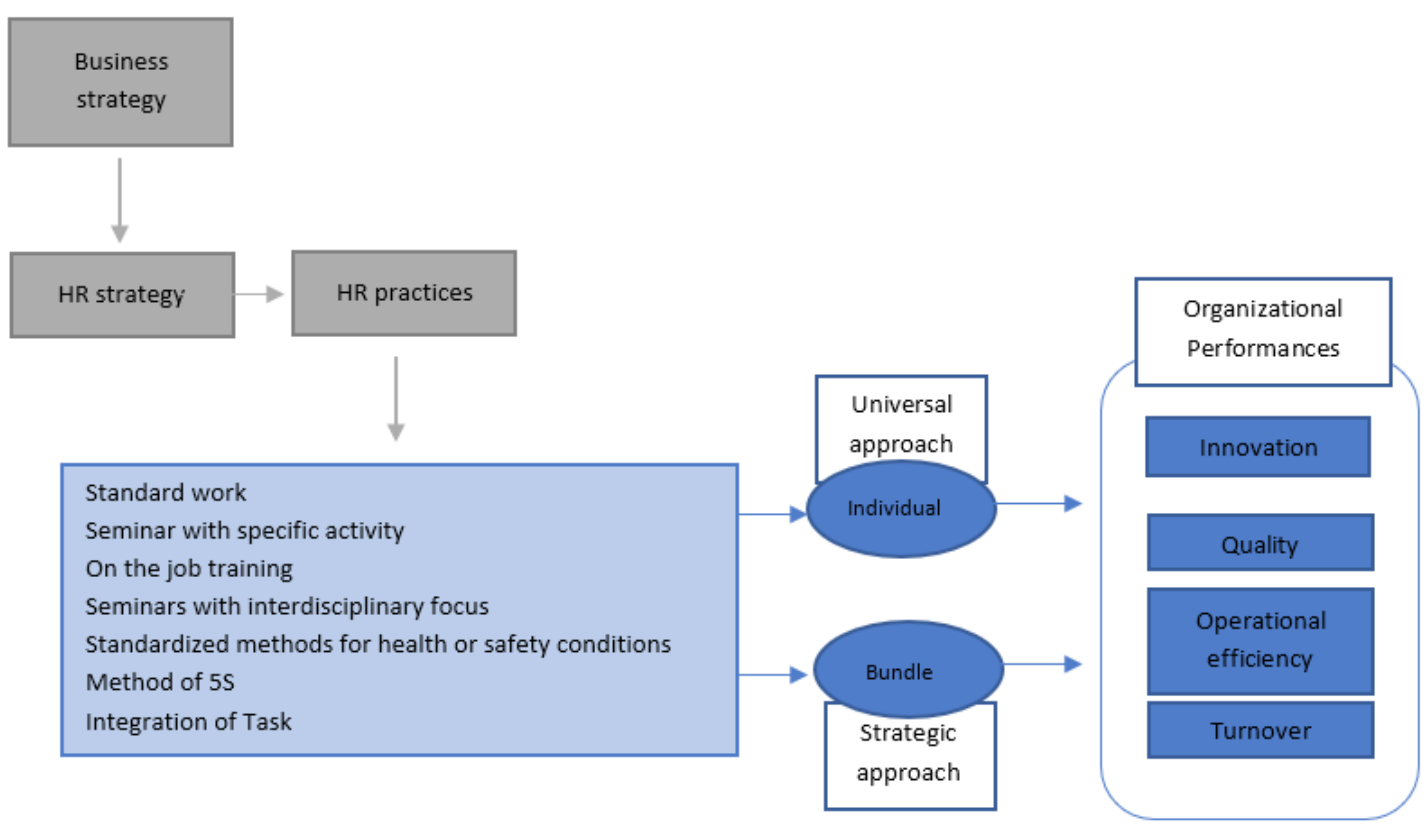

Figure 1. Research model describing how HPWS affect performance 
In 2015, 12 countries were included in the EMS, covering almost three quarters of European manufacturing companies with at least 20 employees belonging to sectors 10-33 of the European Classification of Economics Activities (NACE) [74]. The present study, however, uses data from the EMS Spanish subsample comprised of 101 responses, representing a response rate of $2.5 \%$. The low response rate could be attributed to the survey being non-mandatory and the prevailing economic situation.

\subsection{Operationalization of the variables}

For the present analysis, the responding manufacturing firms were presented with the question, 'Which of the following organizational concepts are currently used in your factory', followed by13 organisational concepts, to which the answer was 'Yes' or 'No'. Aligned with the focus of the present paper, we selected the practices that correspond to the ones identified and grouped in the seminal paper of [6], a classification schema of 61 HPWP organised into nine categories, forming HPWS. From the perspective of this taxonomy, our selection covers HPWP classified in the categories of job and work design, and training and development.

The most implemented combinations were explored in relation to other variables such as innovation, quality, operational efficiency, and turnover outcomes, understood to be performance indicators. A full and detailed description of the variables used and their operationalisation is showed in Table 3. The performance variables were standardised to guarantee comparability between the different measures. The procedure followed to do so was: i) set the value of reference to 100 for all the performance variables; ii) assume that the maximum level of each variable corresponded to 100 ; iii) recalculate the values of all the performance variables according to this assumption, using the rule of three. A careful check and analysis of the outliers for each variable was performed prior to the recalculation procedure.

The data from 101 manufacturing companies were analysed using SPSS, Version 23.

Table 3. Variables used in modelling the relationship between HPWS and performance

\begin{tabular}{|c|c|c|}
\hline Concept & Description & Values \\
\hline \multicolumn{3}{|c|}{ HPWS Practices } \\
\hline Method of $5 S$ & Method of 5S ("workplace appearance and cleanliness") as an organizational concept in use & Yes/No \\
\hline Standard work & $\begin{array}{l}\text { Standardized and detailed working instruction ("standard work") as an organizational con- } \\
\text { cept in use }\end{array}$ & Yes/No \\
\hline Integration of tasks & $\begin{array}{l}\text { Integration of tasks (planning, operating, and controlling functions with the machine opera- } \\
\text { tor) as an organizational concept in use }\end{array}$ & Yes/No \\
\hline $\begin{array}{l}\text { Standardized methods } \\
\text { for health or safety } \\
\text { conditions }\end{array}$ & $\begin{array}{l}\text { Standardized methods of job design for improving health or safety conditions at work (e.g., } \\
\text { Methods-time measurement MTM) as an organizational concept in use }\end{array}$ & Yes/No \\
\hline $\begin{array}{l}\text { Seminars with an ac- } \\
\text { tivity-specific focus }\end{array}$ & $\begin{array}{l}\text { Seminars, training opportunities with an activity-specific focus (e.g., machine maintenance) } \\
\text { as qualifying measures and measures of continuing training applied to employees in produc- } \\
\text { tion }\end{array}$ & Yes/No \\
\hline $\begin{array}{l}\text { Seminars with an inter- } \\
\text { disciplinary focus }\end{array}$ & $\begin{array}{l}\text { Seminars, training opportunities with an interdisciplinary focus (e.g., language courses, } \\
\text { team leadership) as qualifying measures and measures of continuing training applied to } \\
\text { employees in production }\end{array}$ & Yes/No \\
\hline On-the-job training & $\begin{array}{l}\text { On-the-job training (e.g., job rotation, workplace instructions, organized exchange of experi- } \\
\text { ence with colleagues) as qualifying measures and measures of continuing training applied to } \\
\text { employees in production }\end{array}$ & Yes/No \\
\hline \multicolumn{3}{|c|}{ Performance } \\
\hline Innovation & $\begin{array}{l}\text { Share of turnover of products new to the factory or that incorporate major technical chang- } \\
\text { es }\end{array}$ & $\%$ \\
\hline \multirow[t]{2}{*}{ Operational efficiency } & $\begin{array}{l}\text { Average manufacturing lead time of main product (from receipt of order on the shop floor } \\
\text { until shipment) }\end{array}$ & $\begin{array}{l}\text { Workdays } \\
\text { Numeric }\end{array}$ \\
\hline & Percentage of orders delivered on time (as per confirmed delivery date) & $\%$ \\
\hline Quality & Percentage of delivered orders that received complaints from clients due to quality problems & $\%$ \\
\hline Turnover & Annual turnover corresponding to 2014 & $\begin{array}{l}\text { Million } € \\
\text { Numeric }\end{array}$ \\
\hline
\end{tabular}




\section{Results}

Since this study is focused on the Spanish subsample, the first step was to classify the practices implemented by Spanish manufacturing firms using a discriminatory analysis which retained those implemented by more than $50 \%$ of the companies. The results presented in Table 4 show that the most adopted practices were standard work (87\%), followed by seminars with an activity-specific focus (80\%), and on-the-job training (79\%). These three practices were correlated because they focus on standardization designed to increase employee efficiency in their workplace. The next most implemented practice was seminars with an interdisciplinary focus (77\%). Since firms need multifaceted employees with a wide knowledge and skills, they do not train them for specific activities. The method of $5 \mathrm{~S}$ (65\%), integration of tasks (56\%), and standardized methods for health or safety conditions $(50 \%)$ had the lowest rates of implementation (albeit above the 50\% threshold of implementation).

The present study aims to measure the impact the selected HPWP have on specific firm performances individually (H1) and as a HPWS (H2). To this end, and for ease of interpretation, the variables were renamed. For the individual practices, the variables were renamed from $\mathrm{A} 1$ to $\mathrm{A} 7$, and for the combination of practices each bundle was renamed from $\mathrm{U}$ to $\mathrm{Z}$ depending on the number of practices they combined (from 2 to 7 practices) (see Table 5).

A discriminatory analysis was carried out on the companies that simultaneously applied more than one practice to find out the impact selected practices have on the performance studied. A company can apply different sets of practices depending on its objectives. Among all the possible combination of practices, this study only considers the combinations implemented by at least $20 \%$ of the companies.

The degree of implementation of the combinations studied averaged $30 \%$. Table 5 shows that the most implemented bundle of practices was V1 (39.60\%), followed by W1 (37.62\%), X1 (34.65\%), U1 (32.67\%), and V2 and Y1 (almost 28\% each). The least implemented bundle of practices was the combination of seven (Z1), with an implementation rate of $20.79 \%$. Notably, the degree of implementation of these practices in Spanish manufacturing firms is relatively low compared with the European average (55\%) [60], where the highest is $88 \%$ and the lowest just $9 \%$. This absence of implementation may be explained by the economic and financial crisis in Spain during the years when the survey was administered, most of the companies surveyed being SMEs, which were the group most affected by the crisis. These companies may have been willing to implement these strategies but did not have sufficient economic resources to allocate part of the budget to training for innovation. Another important aspect could be the time lag between implementation and

Table 4. Most implemented HPWP by the manufacturing firms studied

\begin{tabular}{|c|c|c|}
\hline & Practices & $\begin{array}{l}\text { Implementation } \\
\text { rate }\end{array}$ \\
\hline \multirow{3}{*}{ 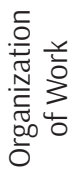 } & Method of $5 S$ & $65 \%$ \\
\hline & Standard work & $87 \%$ \\
\hline & Integration of tasks & $56 \%$ \\
\hline \multirow{4}{*}{$\stackrel{\Upsilon}{\text { I }}$} & Instruments to maintain elderly employees & $23 \%$ \\
\hline & Methods for promoting staff commitment & $40 \%$ \\
\hline & Standardized methods for health or safety conditions & $50 \%$ \\
\hline & Broad-based employee financial participation schemes & $42 \%$ \\
\hline \multirow{6}{*}{ 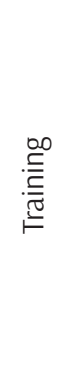 } & Seminars with an activity-specific focus & $80 \%$ \\
\hline & Seminars with an interdisciplinary focus & $77 \%$ \\
\hline & IT- based self-learning programs & $31 \%$ \\
\hline & On-the-job training & $79 \%$ \\
\hline & Information offers (e.g., specialized trade fairs, external databases) & $49 \%$ \\
\hline & Participation in measures for continual quality improvement (e.g., quality circles, groups for CIP) & $44 \%$ \\
\hline
\end{tabular}


impact since the tendency among SMEs is to focus on the short term and these practices require time before they generate returns. Last, smaller companies may consider these practices as useless to them.

\subsection{Individual practices}

Regarding individual practices, the first step was to calculate the significances of the relationships be-

Table 5. The implementation degree of HPWS

\begin{tabular}{|c|c|c|c|c|c|}
\hline \multicolumn{6}{|c|}{ Individual practices } \\
\hline & & Standard work & \multicolumn{3}{|l|}{ A1 } \\
\hline & & Seminars with an activity-specific focus & \multicolumn{3}{|l|}{$\mathrm{A} 2$} \\
\hline & & On-the-job training & \multicolumn{3}{|l|}{ A3 } \\
\hline & & Seminars with interdisciplinary focus & \multicolumn{3}{|l|}{ A4 } \\
\hline & & Standardized methods for health or safety conditions & \multicolumn{3}{|l|}{ A5 } \\
\hline & & Method of $5 S$ & \multicolumn{3}{|l|}{ A6 } \\
\hline & & Integration of Task & \multicolumn{3}{|l|}{ A7 } \\
\hline \multicolumn{6}{|c|}{ Combination of practices } \\
\hline \multirow{2}{*}{ 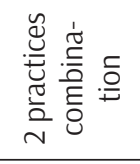 } & \multirow[b]{2}{*}{ U1 } & Standard work & \multirow[b]{2}{*}{$A 1+A 2$} & \multirow[b]{2}{*}{$33 / 101$} & \multirow[b]{2}{*}{$32,67 \%$} \\
\hline & & Seminars with an activity-specific focus & & & \\
\hline \multirow{6}{*}{ 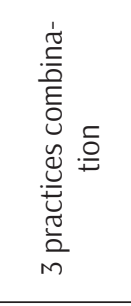 } & \multirow{3}{*}{ V1 } & Standard work & \multirow{3}{*}{$A 1+A 2+A 5$} & \multirow{3}{*}{$40 / 101$} & \multirow{3}{*}{$39,60 \%$} \\
\hline & & Seminars with an activity-specific focus & & & \\
\hline & & Standardized methods for health or safety conditions & & & \\
\hline & \multirow{3}{*}{ V2 } & Standard work & \multirow{3}{*}{$A 1+A 2+A 3$} & \multirow{3}{*}{ 28/101 } & \multirow{3}{*}{$27,72 \%$} \\
\hline & & Seminars with an activity-specific focus & & & \\
\hline & & On-the-job training & & & \\
\hline \multirow{8}{*}{ 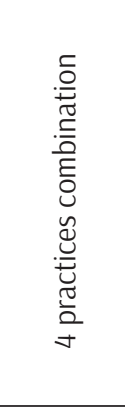 } & \multirow{8}{*}{ W1 } & Standard work & & & \\
\hline & & Seminars with an activity-specific focus & $A 1+A 2+A 3+A 5$ & $38 / 101$ & $37.62 \%$ \\
\hline & & On-the-job training & मानिदिय & ו ו & $3,0<10$ \\
\hline & & Standardized methods for health or safety conditions & & & \\
\hline & & Standard work & & & \\
\hline & & Seminars with an activity-specific focus & $A 1+A 2+A 3+A 4$ & 23/101 & $22,77 \%$ \\
\hline & & On-the-job training & & & \\
\hline & & Seminars with an interdisciplinary focus & & & \\
\hline & & Standard work & & & \\
\hline$\overline{0}$ & & Seminars with an activity-specific focus & & & \\
\hline 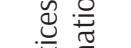 & $\mathrm{X} 1$ & On-the-job training & $A 1+A 2+A 3+A 4+A 5$ & $35 / 101$ & $34,65 \%$ \\
\hline$\frac{\tilde{\pi}}{2}$ & & Seminars with an interdisciplinary focus & & & \\
\hline & & Standardised methods for health or safety conditions & & & \\
\hline & & Standard work & & & \\
\hline$\vec{\Xi}_{\tilde{\Xi}}^{\vec{E}}$ & & $\begin{array}{l}\text { Standardised methods for health or safety conditions } \\
\text { On-the-job training }\end{array}$ & & & \\
\hline 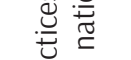 & $\mathrm{Y} 1$ & Seminars with an interdisciplinary focus & $A 1+A 2+A 3+A 4+A 5+A 6$ & 28/101 & $27,72 \%$ \\
\hline$\frac{\pi}{2}$ & & Standardized methods for health or safety conditions & & & \\
\hline & & Method of 5S & & & \\
\hline & & Standard work & & & \\
\hline 釒 & & Seminars with an activity-specific focus & & & \\
\hline $\bar{E}$ & & On-the-job training & & & \\
\hline$\stackrel{8}{u}$ & $\mathrm{Z1}$ & Seminars with an interdisciplinary focus & $A 1+A 2+A 3+A 4+A 5+A 6+A 7$ & $21 / 101$ & $20,79 \%$ \\
\hline$\stackrel{\mathscr{U}}{\underline{U}}$ & & Standardized methods for health or safety conditions & & & \\
\hline$\frac{\pi}{2}$ & & Method of $5 S$ & & & \\
\hline$r$ & & Integration of Task & & & \\
\hline
\end{tabular}


tween implementing these practices individually and the performance studied (Table 6). A one-way ANOVA test was conducted to further investigate the effects of the HPWP on the performances studied.

The individual practice that led to the highest rate of innovation performance was standardized methods for health and safety conditions (A5). Companies that implemented this practice significantly increased their innovation performance (11.5\%). Companies that focused on work standardization (A1) as a sole practice, however, decreased their innovation performance by $4.59 \%$. This decline can be explained by the fact that companies that limit their employees work to a standardised job tend to ensure that they know their job very well and be highly efficient at it, cutting off their creativity and innovation. With these results in mind, we can partially accept $\mathrm{H} 1 \mathrm{a}$ regarding the impact that individual practices have on innovation performance. The results indicate that implementing specific practices might increase or reduce the innovation performance of the organization. Therefore, companies need to be clear about their objectives and know how specific practices might affect their performances.

The second outcome was operational efficiency, measured by the average manufacturing lead time and the orders delivered on time. Individually, two practices significantly influenced companies' lead time: seminars with an activity-specific focus (A2) and on-the-job training (A3). Companies that im- plemented these practices reduced their average by more than 13 days if they introduced seminars and more than 9 days with on-the-job training. Furthermore, companies that introduced seminars with an interdisciplinary focus (A4) increased the number of orders delivered on time by $6.51 \%$. However, the practice of implementing on-the-job training, which also incremented lead time, decreased the percentage of orders delivered on time by $1 \%$. In this case, the results indicate that training employees is greatly beneficial for the company in term of a noticeably reduced lead time. A reduction in the lead time also implies greater worker efficiency and effectiveness, allowing an optimisation of resources. However, if companies allow their employees to have a broad vision of the business and its functions, thus allowing an interdisciplinary focus, employees increase their capacity to deliver the products or services they offer on time. While it is true that access to training can slow down on-time delivery, it can be concluded that the cost-benefit ratio is higher when the practices are applied individually. Taking all the above-mentioned into consideration, we can partially accept $\mathrm{H} 1 \mathrm{~b}$ since the results indicate significant impacts on operational efficiency when specific practices are implemented.

The third performance aspect studied was quality performance, measured by customer complaints. Regarding individual practices, although some results were significant, the impact was relatively low since the practices analysed affected customer satisfaction

Table 6. The relation between the HPWP individually and the performance studied

\begin{tabular}{|c|c|c|c|c|c|c|c|c|c|c|c|c|c|c|}
\hline Individual & $\mathrm{A} 1$ & & $\mathrm{~A} 2$ & & A3 & & A4 & & A5 & & A6 & & A7 & \\
\hline & $\mathrm{F}$ & Sig. & F & Sig. & $\mathrm{F}$ & Sig. & F & Sig. & $\mathrm{F}$ & Sig. & $\mathrm{F}$ & Sig. & $\mathrm{F}$ & Sig. \\
\hline innovation & -4.59 & $0.07 *$ & 7.88 & 0.58 & 7.12 & 0.18 & 1.06 & 0.35 & 11.50 & $0.00 * \star *$ & 11.38 & 0.3 & 6.35 & 0.84 \\
\hline Average & & & & & & & & & & & & & & \\
\hline $\begin{array}{l}\text { Manufacturing } \\
\text { lead time }\end{array}$ & 0.99 & 0.9 & -13.45 & $0.02 * *$ & -9.28 & 0.03 ** & 6.63 & 0.13 & 4.40 & 0.73 & 2.22 & 0.3 & -2.12 & 0.69 \\
\hline $\begin{array}{l}\text { Orders deliv- } \\
\text { ered on time }\end{array}$ & 1.53 & 0.32 & 3.03 & 0.93 & -1.08 & $0.09 *$ & 6.51 & $0.00^{* * *}$ & 1.39 & 0.92 & -0.83 & 0.2 & 1.30 & 0.86 \\
\hline $\begin{array}{l}\text { Complaints } \\
\text { due to quality } \\
\text { problems }\end{array}$ & 0.70 & 0.15 & 0.88 & $0.02^{* *}$ & 0.95 & $0.01 *$ & 0.09 & 0.55 & 0.49 & 0.08 & 0.13 & 0.5 & 0.28 & 0.13 \\
\hline Turnover & 16.74 & 0.79 & 6.01 & 0.97 & -19.77 & 0.45 & 37.75 & $0.03^{* *}$ & 31.48 & 0.32 & 20.68 & 0.6 & 17.10 & 0.53 \\
\hline
\end{tabular}

Notes: ${ }^{*} p<0.1 ;{ }^{* *} p<0.05 ;{ }^{* * *} p<0.00$ 
(A2 and A3) by less than 1\%. This lack of significant results could be because quality outcomes might require a bundle of implemented practices rather than individual ones. Thus, H1c is rejected.

The last performance aspect studied was turnover. Only one practice significantly influenced this outcome: companies that introduced seminars with an interdisciplinary focus (A4) generated a higher turnover $(37.75 \mathrm{M} €)$ than the firms that did not implement this practice individually. Therefore, we can partially accept H1d.

Overall, the individual practices that lead to better performance were the ones related to training. Companies that implemented a training activity individually increased their performance in the different aspects. As the literature evidences, T\&D to enhance employees' requisite skills and potential to learn is perceived to be the most important practice [75]. Once employees have undertaken these programs, the idea is that they apply the acquired knowledge to the task assigned. This means that the higher the level of implementation of T\&D, the better the performance [81]. On the other hand, practices related to work organization (A1, A6 and A7) did not lead to any significant improvements in the performances studied when implemented individually. Taking all the above-mentioned into account, $\mathrm{H} 1$ can be partially accepted as the results indicate that some individual practices have a significant and positive effect on the organizational performances studied.

\subsection{Bundles of practices}

Following the strategy approach, and aiming to resolve $\mathrm{H} 2$, the bundles of practices that lead to better performance depending on firm strategy are studied and discussed as follows (Table 7). The first performance aspect analysed was innovation performance. The results showed that the bundles that only focused on job integration and training (U1 and V2) were concerned with a specific activity and had a negative effect on innovation performance. However, the bundles that considered standardization, different types of training, and/or health and safety methods (W1, W2 and X1) significantly increased innovation performance. These results demonstrate the importance of not only focusing on training when the strategy is bursting innovation. When the aim of the organization is to become more innovative, they should invest not only in training but also in other practices such as standardized methods for health or safety conditions and/or interdisciplinary seminars to promote employee growth.
The results are aligned with Foss \& Laursen (2005) [63], Leede \& Looise (2005) [82], Zoghi et al. (2010) [64], and Weerawardena \& Mort (2006) [83], who show that the bundles that lead to better innovation performance are those that focus not only on the task and training but also on employees' concerns. Similarly, companies that spend time and resources not only on training their employees for a specific workplace but also on developing their multidisciplinary skills are highly likely to transform employees who generate new ideas and become more creative and innovative in their workplace [69]. Thus, we can partially accept $\mathrm{H} 2 \mathrm{a}$.

The bundle that leads to better operational efficiency, understood as the average manufacturing lead time and the percentage of orders delivered on time, was also analysed. When a company's aim is to increase operational efficiency, the results show significances when all the practices are implemented together (Z1), decreasing the lead time average by seven days. This can be explained by employees not only being well-prepared in their workplace through training practices and integration of tasks, but also feeling satisfied that the company considers the health and safety conditions of their workplaces. Moreover, this increase in operational efficiency positively affects the percentage of orders delivered on time: if employees are more productive in their workplace, more orders are delivered on time. To this effect, the results indicate that the companies that implement a group of practices that consider standard work and some type of training (such as U1 and V2) present higher rates of orders delivered on time (increase of 5 to 7 points). These results are in line with Ichniowski and Prenushi [66], who find that companies that implemented HPWS have higher operational efficiency rates than those that do not. Similar results were found by Mohaimen \& Huq (2013) [84], Regan (2011) [50], and Chen \& Huang (2009) [19], among others, concluding that implementing such practices increases employee empowerment and motivates them to increase their efforts to become more productive. Therefore, we can partially accept H2b.

The third performance aspect is quality. Researchers state that some practices, such as standardization, training, and health and safety conditions [85] are designed to motivate and help employees to complete tasks successfully to obtain better quality through increasing efficiency and effectiveness [86], and to improve employee attitudes [69]. Implementing this bundle of practices decreases the number of products scrapped due to quality problems, thus raising the quality performance rate. As Schneider \& 
Bowen (2009) [69] state, to improve quality performance in an organization it is important to create an appropriate environment to help employees focus their efforts on understanding the needs and expectations of their customers. As mentioned above, when workers are aware of their clients' requirements and they work to meet them in a suitable environment, effective practices may facilitate increased quality and reduced complaints due to quality problems [20]. In line with the study conducted by the European Foundation for the Improvement of Living and Working Conditions (2012), the results show that HPWS involving health and safety measures, training, and integrated working practices are the ones most commonly associated with increased quality and, to a lesser extent, with reduced complaints due to quality problems [40]. In this regard, the results shows that when all the 7 practices are implemented together (Z1), complaints due to quality problems decrease by $46.51 \%$. Since quality performances increase, we can partially accept $\mathrm{H} 2 \mathrm{c}$.

The last indicator studied was the impact the bundle of practices might have on turnover (H2d). Abundant empirical research links HPWS and turnover, but there remains a need for results that analyse the bundle that best fits increased turnover $[25,35,70]$. While some studies find a positive relation between these practices and turnover [71], others find no association or a negative one [81]. In this regard, the results presented in this paper show that implement- ing groups of practices that take standardized work, training activities, and health and safety conditions (such as W1, W2 and X1) into consideration has a positive effect on turnover. Thus, we can partially accept H2d.

To sum up, the results indicate that almost all the bundles of practices present an effect on the specific organizational performance studied. Thus, H2 can be accepted as not all the groups of practices affect all performances, or at the same level or with the same impact, despite most of them having significant impacts on the performances studied.

\subsection{A comparison of alternatives for implementation}

Considering all the above-mentioned, companies should implement individual or bundles of practices depending on the strategy they are following. In this regard, H3 analyses whether the bundle of practices has a greater impact than individual implementation. Table 8 provides a detailed overview of the different effects studied in this research.

Focusing on innovation performance, the results indicate that despite the implementation of individual practices presenting a positive effect on performance (the highest impact is with $\mathrm{A} 5$ with a growth of $11.50 \%)$, the impact is larger when implementing the bundle of practice that considers better work conditions, training for employees, and work standardiza-

Table 7. Influence of HPWS on the performance aspects studied

\begin{tabular}{|c|c|c|c|c|c|c|c|c|c|c|c|c|c|c|c|c|}
\hline $\begin{array}{r}\text { Bundle } \\
\text { practices }\end{array}$ & \multicolumn{2}{|c|}{ U1 } & \multicolumn{2}{|c|}{ V1 } & \multicolumn{2}{|c|}{ V2 } & \multicolumn{2}{|c|}{ W1 } & \multicolumn{2}{|c|}{ W2 } & \multicolumn{2}{|c|}{ X1 } & \multicolumn{2}{|c|}{ Y1 } & \multicolumn{2}{|c|}{$\mathrm{Z1}$} \\
\hline & F & Sig. & $\mathrm{F}$ & Sig. & $\mathrm{F}$ & Sig. & $\mathrm{F}$ & Sig. & $\mathrm{F}$ & Sig. & $\mathrm{F}$ & Sig. & $\mathrm{F}$ & Sig. & $\mathrm{F}$ & Sig. \\
\hline innovation & -11.58 & $0.01^{* *}$ & -9.72 & 0.13 & -9.58 & 0.01 ** & 12.58 & $0.04^{*}$ & 7.79 & $0.02^{* *}$ & 5.05 & $0.08 *$ & -5.96 & 0.16 & 17.2 & 0.21 \\
\hline $\begin{array}{l}\text { Average } \\
\text { Manufactur- } \\
\text { ing lead time }\end{array}$ & -2.36 & 0.67 & 2.54 & 0.29 & 6.54 & 0.79 & 2.68 & 0.14 & 3.69 & 0.42 & 2.48 & 0.12 & 5.56 & 0.77 & -7.27 & $0.07^{*}$ \\
\hline $\begin{array}{l}\text { Orders deliv- } \\
\text { ered on time }\end{array}$ & 7.69 & 0.03 ** & 5.05 & 0.16 & 5.78 & $0.02^{* *}$ & 6.58 & 0.88 & 8.53 & 0.11 & 2.36 & 0.94 & 1.02 & 0.95 & 3.39 & $0.01^{* * *}$ \\
\hline $\begin{array}{l}\text { Complaints } \\
\text { due to quality } \\
\text { problems }\end{array}$ & 10.98 & 0.86 & 1.45 & 0.55 & 1.4 & 0.72 & -1.55 & 0.47 & -1.57 & 0.77 & 1.67 & 0.34 & 1.35 & 0.64 & -46.51 & $0.06^{*}$ \\
\hline Turnover & 35.89 & 0.25 & 109.69 & 0.58 & 40.04 & 0.21 & 74.29 & $0.03^{* *}$ & 60.87 & $0.03^{* * *}$ & 110.64 & $0.01^{* *}$ & 58.54 & 0.73 & 99.08 & 0.51 \\
\hline
\end{tabular}

Notes: ${ }^{*} p<0.1 ;{ }^{* *} p<0.05 ; * * * p<0.00$ 
tion (12.58\%). Thus, we can accept H3a.

To increase operational efficiency, this paper focuses on two different indicators: the reduction of the lead time manufacturing days and the increase in the number of orders delivered on time. Regarding the lead time, the results indicate that despite implementing all the practices together (Z1), the lead time only reduced by 7 days. The biggest impact appeared when the company invested their resources in the individual practice of training their employees with activity-specific seminars (A2), resulting in a reduction of over 13 days. On the other hand, when the strategy of the company was to focus on increasing the number of orders delivered on time, the results changed. The greatest impact appeared when the company implemented standard work and specific training activities (U1). However, if the company is looking to increase their operational efficiency in general, they should implement the bundle of practices $\mathrm{Z} 1$ since this unique combination will simultaneously reduce lead time and increase the percentage of orders delivered on time. Thus, H3b is accepted.

Quality performance aims to reduce quality complaints to increase customer satisfaction. In this regard, all the individual practices present either no significances or a negative impact. However, implementing all 7 practices together $(\mathrm{Z} 1)$ as a bundle increases quality performance by more than $46 \%$. Thus, we can accept H3c.

Last, the results indicate that turnover increases most when the combination of training, work standardization, and methods to increase employees health and safety conditions (X1) is implemented. Overall, we can accept H3, which indicates that implementing bundles of practices present better results that implementing individual ones.

\section{Conclusions}

The main objective of this research was to analyse the difference between implementing specific practices separately and as a bundle, and their effect on different performance aspects (innovation, operational efficiency, quality, and turnover). The paper makes several contributions. First, it provides recent and relevant data on including HPWS in Spanish manufacturing surveys; second, it shows the degree of implementation of these practices in the Spanish context; third, it produces new results on how specific practices implemented separately affect different aspect of performance; and fourth, it shows how HPWP implemented as a bundle affects different aspects of performance.

The results show that the rates of implementa-

Table 8. Summary of the results

\begin{tabular}{|c|c|c|c|c|c|}
\hline & Innovation (\%) & $\begin{array}{l}\text { manufacturing lead } \\
\text { time (days) }\end{array}$ & Orders on time (\%) & Complaints (\%) & Turnover $(€)$ \\
\hline A1 & -4.59 & 0 & 0 & 0 & 0 \\
\hline A2 & 0 & -13.45 & 0 & 0.88 & 0 \\
\hline A3 & 0 & -9.28 & -1.08 & 0.95 & 0 \\
\hline A4 & 0 & 0 & 6.51 & 0 & 37.75 \\
\hline A5 & 11.50 & 0 & 0 & 0 & 0 \\
\hline A6 & 0 & 0 & 0 & 0 & 0 \\
\hline A7 & 0 & 0 & 0 & 0 & 0 \\
\hline U1 & -11.58 & 0 & 7.69 & 0 & 0 \\
\hline V1 & 0 & 0 & 0 & 0 & 0 \\
\hline V2 & -9.58 & 0 & 5.78 & 0 & 0 \\
\hline W1 & 12.58 & 0 & 0 & 0 & 74.29 \\
\hline W2 & 7.79 & 0 & 0 & 0 & 60.87 \\
\hline $\mathrm{X} 1$ & 5.05 & 0 & 0 & 0 & 110.64 \\
\hline Y1 & 0 & 0 & 0 & 0 & 0 \\
\hline $\mathrm{Z1}$ & 0 & -7.27 & 3.39 & -46.51 & 0 \\
\hline
\end{tabular}


tion in Spanish manufacturing firms are relatively low. As discussed above, this could be due to several circumstances such as the economic climate, lack of knowledge, managers considering implementing these practices as unnecessary due to the small size of the company, and so on. However, despite this low rate of usage, more than $50 \%$ of the companies implement some of the practices studied (individually or as a bundle). The practices most implemented by Spanish manufacturing firms are grouped into three conceptual blocks (organizational work, implementation, and retention and training activities), which are matched with different performance aspects resulting in the following conclusions.

The practice that leads to better performance individually is training. As explained above, when a company dedicates time to training its employees they apply the acquired knowledge to the task and job assigned, increasing intermediate and final outcomes. A second conclusion is the importance of introducing health and safety methods when a firm implements a bundle of practices. All the bundles studied that do not include this practice have a negative impact on turnover, while the bundles that introduce these methods have positive impacts on this performance aspect. Last, it is important that companies know which bundles lead to better performance aspects. The one that leads to better turnover considers training, health and safety conditions, and work standardization. These three practices provide employees with the specific training needed to help them carry out their task and to understand that they are important and safe within the company.

This paper makes a series of contributions. It contributes with new insights and knowledge of companies' competitive strategies that include or envisage HPWP implementation. We build on the existing body of knowledge of HPWS and contribute with valuable and recent empirical evidence formulating individual and bundle alternatives for implementation. Providing performance explanatory trajectories is in the main interest of practitioners, including implementers, solution providers and consultants. The relatively low implementation levels of HPWP might be related to their unknown expected benefits or effects on performance, to the organisation-wide changes they involve, or the possible immaterial advantages they drive. Our study may motivate non-implementers to initiate implementation of HPWP, possibly starting with some individual ones, provided they are in line with the company strategy, mission, and vision. The firms that are more advanced in implementing HPWP and want to introduce additional organisational practices can also be inspired by our findings, especially when they willing to implement a combination of multiple practices that impact both intermediate performance measures (innovation, quality, operational efficiency) and ultimate turnover aspects.

While this study makes several contributions, there are various ways in which it could be improved and advanced from a conceptual and methodological perspective. First, the small number of responses limits the generalization of the findings. However, while relatively small, our sample size is consistent with many studies in the innovation and HPWS literature [26] that use data from voluntary surveys. Therefore, we hope that future research replicates our results with larger data sets. Further research could also consider the inclusion of data from other countries using the same questionnaire to enrich and strengthen the analysis. The number of practices studied might be considered a limitation, and future analyses could include other practices such as selection and compensation to supplement the results of the present study.

\section{Funding}

This research was funded by MINECO/AEI/ FEDER/EU: ECO2017-86054-C3-3-R.

\section{References}

[1] M. D. Mijatović, O. Uzelac, and A. Stoiljković, "Effects of human resources management on the manufacturing firm performance: Sustainable development approach,” Int. J. Ind. Eng. Manag., vol. 11, no. 3, pp.205 - 212, 2020.

[2] M. Zhang, D. Di Fan, and C. Zhu, "High-Performance Work Systems, Corporate Social Performance and Employee Outcomes: Exploring the Missing Links,”J. Bus. Ethics, vol.120, no. 3, pp.423-435, 2014.

[3] V. Oladapo, and G. Onyeaso, "An Empirical Investigation of Sub Dimensions of High Performance Work," Int. J. Manag. Bus. Res., vol.6, no.1, pp.67-80, 2013.

[4] P. Patel, J. Messersmith, and D. Lepak, "Walking the Tightrope: An Assessment of the Relationship between High-Performance Work Systems and Organizational Ambidexterity" Acad Manage J, vol.56, no. 5, pp.1420-1442, 2013.

[5] M. Demirbag, D. Collings, E. Tatoglu, K. Mellahi, and G. Wood, "High-Performance Work Systems and Organizational Performance in Emerging Economies: Evidence from MNEs in Turkey" Manag. Int. Rev., vol.54, no. 3, pp.325-359, 2014.

[6] R. Posthuma, C. Campion, M. Masimova, and M. Campion "A high performance work practices taxonomy: Integrating the literature and directing future research,” J. Manage., vol.39, no. 5, pp.1184-1220, 2013.

[7] B. Kroon, K. Van De Voorde, and J. Timmers "High performance work practices in small firms: A resource -poverty and strategic decision-making perspective," Small Bus. Econ., vol.41, no. 1, pp.71-91, 2013. 
[8] A. Danford, M. Richardson, P. Stewart, S. Tailby, and M. Upchurch, "Partnership, high performance work systems and quality of working life. New Technology, Work and Employment, vol.23, no. 3, pp.151-166, 2008.

[9] D. Guest, "Human resource management and performance: Still searching for some answers," Hum. Resour. Manag. J., vol.2, no.1, pp.3-13, 2011.

[10] J. Arthur, "Effects of Human Resource Systems on Manufacturing Performance and Turnover," Acad Manage J, vol.37, no.3, pp.670-687, 1994.

[11] H. Ramsay, D. Scholarios, and B. Harley, "Employees and High-Performance Work Systems: Testing inside the Black Box," Br J Ind Relats, vol. 38, no. 4, pp.501-531, 2000.

[12] B. Harley, Hope or hype? High-performance work systems in Harley Palgrade Mcmilligan., Houndmills, 2007.

[13] K. Macky, and P. Boxall, "The relationship between high-performance work practices and employee attitudes: an investigation of additive and interaction effects," Int. J. Hum. Resour. Manag., vol.18, no. 4, pp.537-567, 2007.

[14] J. Guthrie, P. Flood, W. Liu, and S. MacCurtain, "High performance work systems in Ireland: human resource and organizational outcomes” Int. J. Hum. Resour. Manag., vol.20, no.1, pp.112-125, 2009.

[15] S. Ismail, "The Impact of High Performance Work Systems' on Firm Performance in MNCs and Local Manufacturing Firms in Malaysia," Int. J. Econ. Manag., vol.6, no. 11, pp.553-563, 2012.

[16] A. Katou, "Measuring the impact of HRM on organizational performance,” J. Ind. Eng. Manag., vol.1, no. 2, pp.119$142,2008$.

[17]J. Messersmith, and P. Guthrie, "High performance work systems in emergent organizations:implications for firm performance," Hum Resour Manage, vol.49, no. 2, pp. 241-264, 2010.

[18] F. Pot, P. Totterdill, and S. Dhondt, "Workplace innovation: European policy and theoretical foundation," Wor ld Rev. Entrep. Manag. Sustain. Dev., vol. 12, no. 1, p.13, 2016.

[19] C. Chen, and J. Huang, "Strategic human resource practices and innovation performance - The mediating role of knowledge management capacity” J. Bus. Res., vol.62, no. 1, pp.104-114, 2009 .

[20] F. Richardson, Enhancing Strategies to Improve Workplace Performance, Walden University, 2014.

[21] N. Wu, K. Hoque, N. Bacon, and J.C. Bou Llusar, "High-performance work systems and workplace performance in small, medium-sized and large firms," Hum. Resour. Manag. J., vol.25, no. 4, pp.408-423, 2015.

[22] European Innovation Scoreboard, 2020 (EC, 2021) accessed June 2021, available at: https://ec.europa.eu/ growth/industry/policy/innovation/scoreboards_en

[23] D. Nadler, The handbook of human resource development (2nd ed.), New York: Wiley, 1990.

[24] B. Becker, and M. Huselid, "Strategic Human Resources Management: Where Do We Go From Here?,”J Manage., vol.32, no. 6, pp.898-925, 2006.

[25] P. Boxall, and J. Purcell, Strategy and Human Resource Management., London: Palgrave Macmillan, 2011.

[26] M. Úbeda-García, E. Claver-Cortés, B. Marco-Lajara, P. Zaragoza-Sáez, and F. García-Lillo, "High performance work system and performance: Opening the black box through the organizational ambidexterity and human re source flexibility," J. Bus. Res., vol. 88, pp. 397-406, 2018.

[27] M. Huselid, "The Impact of Human Resource Management Practices on Turnover, Productivity, and Corporate Financial Performance,” Acad Manage J, vol.38, no. 3, pp. 635-872, 1995.

[28] J. Delaney, and M. Huselid, "The Impact of Human Resource Practices on Perceptions Organizational
Performance,” Acad Manage J, vol. 39, no. 4, pp. 949-969, 2016.

[29] OECD, 2016. Organisation for Economic Co -operation and Development (OECD). Available at: http://www.oecd.org/.

[30] P. Osterman, "Work reorganization in an era of restructuring: trends in diffusion and effects on employee welfare,” Ind Labor Relat Rev, vol. 53, no. 2, pp.179-196, 2000

[31] S. A. Way, "High performance work systems and intermediate indicators of firm performance within the US small business sector,” J Manage., vol.28, no. 6,pp.765-785, 2002.

[32] P. Tamkin, High Performance Work Practices. Institute for employees. IES Research Networks, 2004.

[33] T. Bauer, High Performance Workplace Practices and Job Satisfaction: Evidence from Europe. Institute for the Study of Labor (IZA), 2005.

[34] J. Godard, "A critical assessment of the high-performance paradigm,” Br. J. Ind. Relat., vol.42, no. 2, pp.349-378, 2004 .

[35] M. Marchington and A. Wilkinson, "Human Resource Management at Work. London, CIPD manufacturing firms," Thunderbird Int. Bus. Rev., vol.49, no. 1, pp.1-35, 2008.

[36] C. Parsons, and R. Necochea, "High Performance Work Systems in the Paper Industry," Work systems, vol.123, no. 4, pp.28-31, 2007.

[37] M. Subramony, "A meta-analytic investigation of the relationship between HRM bundles and firm performance" Hum Resour Manage, vol.48, no. 5, pp.745-768, 2009

[38] N. Soens, D. Buyens, and M. S. Tailor, "First-Line Implementation of High-Performance Work Systems: Exploring Direct and Mediated Relationships With Work Unit Performance," Vlerick Leuven Gent Working Paper Series 2012/05, 2011.

[39] L. O'Regan, “The Impact of High Performance Work Systems on Innovation Performance: A Study of Irish Companies,” Hum. Res. Manage. J., vol.9, no. 1, pp.147-66, 2011.

[40] Eurofound, 2012. Fifth European Working Conditions Survey, Available at: http://www.archidok.eu/ search/classification/x01804/page:2/sort:Corpbody/www. uni-mannheim.de/edz/pdf/eurostat/07/KS-RA-07-027 -FR.pdf.

[41] P. Kumar, L. Jena, and N. Panigrahy, "Learning and development practices in international context: conceptual introspection towards bringing the best work place strategies," Strategic HR Review, vol.15, no. 4, pp.180-186, 2016.

[42] D. Mihail, M. Links, and S. Sarvanidis, "High performance work systems in corporate turnaround: A German case study,”J. Organ. Chang. Manag., vol.26, no. 1, pp.190-216, 2013.

[43] R. García-Chas, E. Neira-Fontela, and C. Varela-Neira, "High-performance work systems and job satisfaction: A multilevel model," J. Manag. Psychol., vol.31, no. 2, pp.451-466, 2016.

[44] Eurofound, 2015. Developments in working life in Europe : EurWORK annual review 2014

[45] Y. Lin, and N. Liu, "High performance work systems and organizational service performance: The roles of different organizational climates," Int. J. Hosp. Manag., vol.55, pp.118-128, 2016.

[46] J. Daspit, K. Madison, T. Barnett, and R. Long, "The emergence of bifurcation bias from unbalanced families: Examining HR practices in the family firm using circumplex theory," Hum. Resour. Manage. Rev., vol. 28, no. 1, pp. $18-32,2018$ 
[47] D. Kooij, and C. Boon, "Perceptions of HR practices, person-organization fit, and affective commitment: The moderating role of career stage," Hum. Resour. Manag. J., vol. 28, no. 1, pp.61-75, 2018.

[48] Y. Lazim, N. Azizan, and S. Sorooshian, "How are the Performance of Small Businesses Influenced by HRM Practices and Governmental Support?" Mediterr. J. Soc. Sci., vol.6, no. 1, pp.97-108, 2015.

[49] J. Gould-Williams, and M. Gatenby, "The Effects of Organizational Context And Teamworking Activities On Performance Outcomes," Public Manag. Rev., vol.12, no. 6, pp.759-787, 2010.

[50] C. Regan, "The Impact of High Performance Work Systems on Innovation Performance: A Study of Irish Companies,” Dublin City University, 2011.

[51] A. Katou, and P. Budhwar, "Causal relationship between HRM policies and organisational performance: Evidence from the Greek manufacturing sector," Eur. Manag. J., vol.28, no. 1, pp.25-39, 2010.

[52] D. Jones, P. Kalmi, and A. Kauhanen, "How Does Employee Involvement Stack Up? The Effects of Human Resource Management Policies on Performance in a Retail Firm,” Ind. Rel., vol. 49, no. 1, pp.1-21, 2010.

[53] Y. Gong, K. Law, S. Chang, and K. Xin, "Human resources management and firm performance: The dif ferential role of managerial affective and continuance commitment," J Appl Psychol, vol.94, no. 1, pp.263-275, 2009.

[54] N. Martín-Cruz, V. Martín-Pérez, and C. Trevilla-Cantero, "The influence of employee motivation on knowledge transfer,” J. Knowl. Manag., vol.13, no. 6, pp.478-490, 2009.

[55] C. Chuang, and H. Liao, "Strategic Human Resource Management in Service Context: Taking Care of employees and customers," Pers. Psychol., vol.63, no. 1, pp.153-197, 2009.

[56] A. Zacharatos, J. Barling, and R. Iverson, "High -performance work systems and occupational safety," J Appl Psychol, vol.90, no. 1, pp.77-93, 2005.

[57]J. Gould-Williams, Human resource management. In R. Ashworth, G. Boyne, \&amp; T. Entwistle. Public service improvement: Theories and evidence., New York: Oxford University Press, 2010.

[58] B. Becker, and M. Huselid, "High Performance Work Systems and Firm Performance: A Synthesis of Research and Managerial Implications," Res. Pers. Hum. Resour. Manag., vol.16, no. 3, pp.53-101, 1998.

[59] D. Guest, J. Paauwe, and W. Wright, HRM and Performance: Achievements and Challenges. John Wiley \& Sons, 2012.

[60] European Found, 2017. European Foundation for the improvement of living and working conditions. Available at: www.eurofound.com.

[61] A. Glaister, G. Karacay, M. Demirbag, and E. Tatoglu, “ HRM and performance: The role of talent management as a transmission mechanism in an emerging market context," Hum. Resour. Manag. J., vol.28, no. 1, pp.148-166, 2018.

[62] I. Korobaničová, and N. Kováčová, "Human capital investment: practices and measurement in Slovak enterprises,” Int. J. Ind. Eng. Manag., vol.9, no. 3, pp.139146,2018

[63] N. Foss, and K. Laursen, "Performance pay, delegation and multitasking under uncertainty and innovativeness: An empirical investigation,” J. Econ. Behav. Organ., vol.58, no. 2, pp.246-276, 2005.

[64] C. Zoghi, R. Mohr, and P. Meyer, "Workplace organization and innovation,” Can. J. Econ., vol.43, no. 2, pp.622-639, 2010.

[65] C. Ichniowski, K. Shaw, and G. Prenushi, "The Effects of
Human Resource Management Practices on Productivity : A Study of Steel Finishing," Am. Econ. Rev., vol.87, no. 3, pp.291-313, 1997.

[66] S. Black, and L. Lynch, "What's driving the new economy?: the benefits of workplace innovation,” Econ. J., vol. 114, pp. 97-116, 2004.

[67] A. Valeyre, E. Lorenz, D. Cartron, P. Csizmadia, M. Gollac, M. Illéssy, and C. Makó, "Working conditions in the European Union: Work organisation," European Foundation for the mprovement of Living and Working Conditions, 2009.

[68] E. Bigné, M. A. Moliner, and J. Sánchez, « Perceived quality and satisfaction in multiservice organisations: the case of Spanish public services," J. Serv. Mark., vol.17, no. 4, pp.420-442, 2003.

[69] B. Schneider, and D. Bowen, "Modeling the Human Side of Service Delivery,” Serv. Sci., vol.1, no. 3, pp.154-168, 2009.

[70] J. Combs, Y. Liu, A. Hall, and D. Ketchen, "How much do high-performance work practices matter? A meta -analysis of their effects on organizational performance," Pers. Psychol., vol.59, pp.501-528, 2006.

[71] S. Wood, and T. Wall, "Work enrichment and employee voice in human resource management-performance studies,” Int. J. Hum. Resour. Manag, vol.18, no. 7, pp.1335-1372, 2007.

[72] S. Wood, "Human ResourceManagement and performance,” Int. J Manage. Rev., vol.1, pp.367-413, 1990 .

[73] T. Hong, "Research methods: when process complements goals," J. Am. Soc. Inf. Sci. Tec., vol.63, no. 11, pp. 2283-2293, 2012.

[74] ISI Institute, 2017. European Manufacturing survey. Fraunhofer ISI Institute from Germany. Available at: http://www.isi.fraunhofer.de/isi-en/.

[75] B. Dachs, S. Biege, M. Borowiecki, G. Lay, A. Jager, and D. Schartinger, "Servitisation of European manufacturing: evidence from a large scale database," Serv. Ind. J., vol.34, no. 1, pp.5-23, 2014.

[76] B. Dachs, S. Kinkel, and A. Jäger, "Bringing it all back home? Backshoring of manufacturing activities and the adoption of Industry 4.0 technologies," J. World Bus., vol. 54, no. 6, $101017,2019$.

[77] A. Bikfalvi, A. Jäger, and G. Lay, "The incidence and diffusion of teamwork in manufacturing - evidences from a Pan-European survey," J. Organ. Chang. Manag., vol.27, no. 2, pp.206-231, 2014.

[78] M. Pons, A. Bikfalvi, J. Llach, and I. Palcic, "Exploring the impact of energy efficiency technologies on manufacturing firm performance,” J. Clean. Prod., vol.52, pp.134-144, 2013.

[79] A. Manresa, A. Bikfalvi, and A. Simon, "The impact of training and development practices on innovation and financial performance," Ind. Commer. Train., vol. 51, no. $7 / 8$, pp. 421-444, 2019.

[80] A. Manresa, A. Bikfalvi, and A. Simon, "The Use and Determinants of Training and Development for Creativity and Innovation International” J. Innov. Manag., vol. 22, no. 02, pp. 1-28, 2018.

[81] C. Tan, and A. Nasurdin, "Human Resource Management Practices and Organizational Innovation: Assessing the Mediating Role of Knowledge Management Effectiveness, ” Electronic J. Knowl. Manag., vol.9, no. 2, pp.155-167, 2011.

[82] J. Leede, and J. Looise, "Innovation and HRM: Towards an integrated framework," Creativity Innov. Manag., vol.14, no. 2, pp.108-117, 2005.

[83] J. Weerawardena, and G. S. Mort, "Investigating social entrepreneurship: A multidimensional model,” J. World 
Bus., vol.41, no. 1, pp.21-35, 2006.

[84] M. Mohaimen, and M. Huq, "High-Performance Work System: An Essential Means,” Int. J. Arts Commerce, vol.2, no. 6, pp.175-186, 2006.

[85] I. Beltran-Martin, V. Roca-Puig, A. Escrig-Tena, and J. Bou-Llusar, "Human Resource Flexibility as a Mediating Variable Between High Performance Work Systems and Performance,” J Manage., vol. 34, no. 5, pp.1009-1044, 2008. 